\title{
STEEL FIBRE REINFORCED CONCRETE FOR TUNNEL LINING - VERIFICATION BY EXTENSIVE LABORATORY TESTING AND NUMERICAL MODELLING
}

\author{
JAROslav BeŇo ${ }^{a, b, *}$, MATOuš Hilar ${ }^{a, c}$ \\ ${ }^{a}$ Faculty of Civil Engineering, Czech Technical University in Prague, Thákurova 7, 16629 Prague, Czech \\ Republic \\ ${ }^{b}$ Metrostav a.s., Koželužská 2246, 18000 Prague, Czech Republic \\ ${ }^{c}$ 3G Consulting Engineers s.r.o., Na Usedlosti 16, 14700 Prague, Czech Republic \\ * corresponding author: Jaroslav.Beno@metrostav.cz
}

\begin{abstract}
The use of precast steel fibre reinforced concrete (SFRC) for tunnel segments is a relatively new application of this material. It was first applied in Italy in the 1980s. However, it did not begin to be widely applied until after 2000. The Czech Technical University in Prague (CTU), together with Metrostav, carried out a study to evaluate the use of this new technology for tunnels in the Czech Republic. The first tests were carried out on small samples (beams and cubes) produced from SFRC to find an appropriate type and an appropriate dosage of fibres. The tests were also used to verify other factors affecting the final product (e.g. production technology). Afterwards, SFRC segments were produced and then tested at the Klokner Institute of CTU. Successful test results confirmed that it was possible to use SFRC segments for Czech transport tunnels. Consequently a $15 \mathrm{~m}$-long section of segmental lining generated from SFRC without steel rebars was constructed as part of line A of the Prague metro.
\end{abstract}

KEYwords: Steel fibre reinforced concrete, segmental tunnel lining, mechanical excavation, laboratory testing.

\section{INTRODUCTION}

Steel fibre reinforced concrete (SFRC) is a relatively new structural material. In the past, it was used mainly for construction of industrial floors. Nowadays, SFRC often replaces steel bar reinforced concrete; the tunnel lining from precast segments is one of many examples. In tunnelling SFRC is used in three basic modifications - sprayed concrete for primary outer lining, in situ cast concrete for the secondary inner lining, and precast segments for tunnels constructed with tunnelling shields. The main advantages of SFRC over widely-used steel bar reinforced concrete (RC) segments are as follows: simple production, higher durability, lower consumption of steel, lower number of defects, etc. A major disadvantage of SFRC segments without steel rebars is their lower bending capacity.

Uniformly distributed and randomly oriented fibres transform brittle plain concrete into ductile SFRC. SFRC can be used to replace plain concrete or reinforced concrete. The steel fibres improve the mechanical properties of the concrete. The fibres carry local tensions caused by three-dimensional stress between aggregate particles. Fibres in concrete enhance its compressive strength, but especially SFRC tensile strength is higher. SFRC has high resistance against the development of microcracks. This feature is related to SFRC's high resistance against dynamic load and resistance against sudden temperature changes.

The physical and mechanical properties of SFRC are influenced by several factors: the material of the fibres, the shape of the fibres (especially adjustment of the ends), the amount of added fibres, and the composition of the concrete mixture. It is necessary to ensure uniform distribution of fibres in the concrete, and to ensure that they are well coated with cement mortar. SFRC cannot be generated just by adding fibres to a standard concrete mix. The composition of the SFRC mix has to be designed taking into account the increased volume of the aggregate caused by fibres. The dosage of fibres is determined by McKee's theory. The minimum amount of fibres depends on their length and thickness. Some types of fibres can generate conglomerates during the mixing process; they should therefore be added to the mix using dosing and dispersing equipment before mixing.

The length of the fibres length should be approximately three times the maximum aggregate size. This will bridge cracks located on the border of the grains, and avoiding pulling out of fibres during the development of these cracks. The strength of SFRC parameters depend mainly on the aspect ratio of the fibres (length to diameter) and on the dosage of fibres (when there is the same concrete matrix). A higher aspect ratio (or a higher fibre content) generally means better performance of the SFRC.

SFRC is especially suitable for structures loaded in more than one direction, where traditional bar reinforcement is problematic. This means that SFRC 

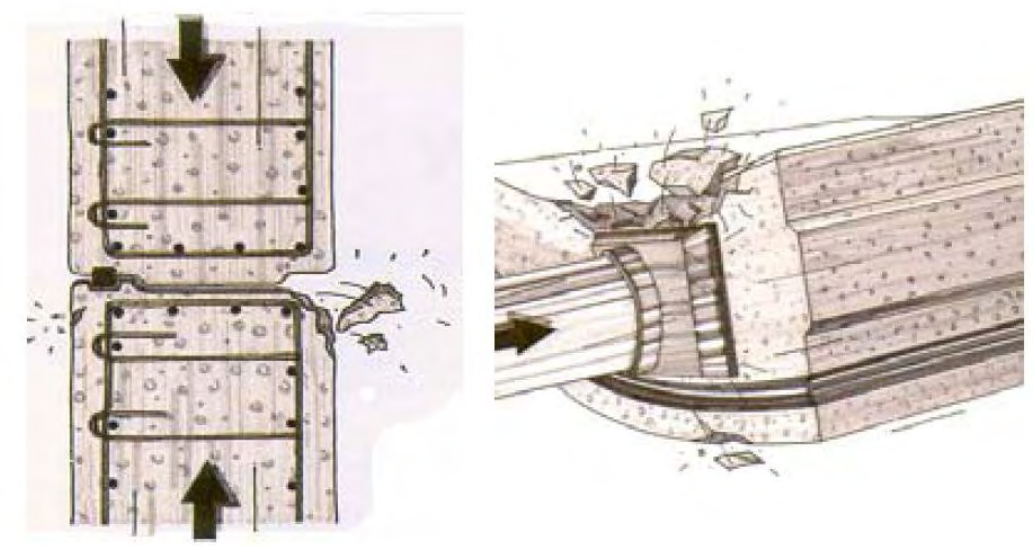

FIGURE 1. Spalling of unreinforced edges of traditionally reinforced segments [1]

is not appropriate for unidirectionally loaded structures, because the randomly oriented fibres would be largely unloaded. SFRC is therefore suitable for tunnel segments loaded in various directions during their production, installation and permanent function. Polypropylene (PP) fibres cannot be used as a reinforcement for concrete structures, because they have a low modulus of elasticity (lower than concrete), which means big deformations. Moreover, PP fibres lose their mechanical properties at $50^{\circ} \mathrm{C}$ and melt at $165^{\circ} \mathrm{C}$. PP fibres can be used in SFRC structures or in reinforced concrete structures to increase their fire resistance.

\section{Segmental tUnNEL Lining}

Tunnel linings constructed from precast reinforced concrete segments started to be used in the 1950s, when they gradually replaced steel and cast-iron segments. Reinforced concrete linings from precast segments were widely used in the construction of the metro in Prague, where the lining was not waterproof due to the manufacturing tolerances. Water-tightness of the lining was reached by additional grouting of the joints between segments, but the risk of leakage was relatively high. Modern segmental linings have manufacturing tolerances of $\pm 0.5 \mathrm{~mm}$, and water tightness is guaranteed by impermeable concrete together with EPMD (ethylene propylene diene monomer) gaskets between the segments. SFRC segments can have complicated details, as every part of the segment is uniformly reinforced by fibres (Fig. 1). There is therefore less damage of segments during transportation and installation, which means that there is a lower risk of leakage and fewer repairs are required.

Nowadays segmental lining is used only in mechanical tunnelling with tunnelling shields (Tunnel Boring Machine technology - TBM). A permanent lining is installed directly behind the tunnel face under the shield protection. The lining has a circular shape composed of several precast concrete segments. Each segment is placed in the required position by the erec- tor (a hydraulic arm at the rear part of the shield). One ring usually has dimensionally identical segments; the final segment (the key segment) has a different shape and is smaller in size. Individual segments are connected by bolts. The space between the lining and the ground is grouted.

Segments are loaded by a wide range of loading conditions during their lifetime. Similarly to other precast structures, the segments have to endure demoulding, manipulation, storage and transportation to the construction site. They also have to carry loads during their installation, namely they should be able to carry the axial forces generated by the hydraulic rams that push the shield into the ground. The load generated by shield rams is often decisive for the design of the segments. All load cases mentioned here are only temporary. The segments are loaded only by ground pressure and hydrostatic pressure during tunnel operation. This load case should correspond with the reinforcement of the segments.

\section{A COMPARISON OF TRADITIONALLY REINFORCED SEGMENTS AND SFRC SEGMENTS}

SFRC segments are suitable for structures without high bending moments. A tunnel lining constructed by tunnelling shields is circular in shape, which is advantageous due to the low bending moments. In standard geotechnical conditions, the segments are loaded mainly by compression with relatively small eccentricity (i.e. without bending and without tensile stress).

After reaching tensile strength, the deformation of SFRC does not increase abruptly, but thanks to the uniformly distributed fibre deformations it increases gradually and causes a greater number of small cracks. This is because the fibres are activated and are continuously pulled out from the concrete. The cracks are relatively small, and the crack openings remain small. The total value of the tensile strength of the segments 
is significantly lower than in the case of bar-reinforced concrete segments.

The behaviour of reinforced concrete is different. After reaching tensile strength, the increment of the deformation develops until full activation of the bar reinforcement. This results in wider cracks than in the case of SFRC, and one main crack usually appears. Afterwards, however, the deformation stabilizes and grows approximately linearly, until it reaches the yield strength of steel bars. This is significantly higher than the strength of steel fibre reinforced concrete in tension. Destruction of the structure occurs after reaching the ultimate strength of steel in tension or crushing of concrete in compression.

SFCR structures are better protected against corrosion. This is mainly because there are lower crack openings than in the case of traditionally reinforced concrete structures. Adding fibres into concrete reduces crack openings in the same segment from 1 $\mathrm{mm}$ to less than $0.2 \mathrm{~mm}$. Minimal opening of cracks allows them to close and self-heal. For this reason, SFRC segments are considered to have about $20 \%$ longer durability than traditionally reinforced structures. Durability of 120 years is expected for some SFRC structures (e.g. tunnels on the Channel Tunnel Rail Link in the United Kingdom).

Minimum cover of the steel rebars is required for traditionally reinforced segments. The minimum cover prevents corrosion of the steel bar reinforcement. The required cover is usually $40-50 \mathrm{~mm}$ in thickness; it depends on the aggressiveness of the external and internal environment (e.g. underground water). No cover is required for SFRC segments, as no reinforcement corrosion is expected. The fibres are completely protected by the alkaline environment of the concrete. In addition, no stray current corrosion can occur in SFRC segments, because the fibres are short and they do not touch each other. Therefore the thickness of SFRC segments can be reduced in some cases.

The production cost of SFRC segments is often slightly lower than the production cost of RC segments, although the actual material (steel fibres) is more expensive than a conventional steel bar reinforcement. Savings can be achieved by lower labour costs and by reducing the amount of steel that is used. The fibres are added directly into the mix. SFRC segments can therefore be produced faster, and the plant can have a higher capacity. The final cost is also reduced by the fact that fewer segments are damaged during installation, so that expensive repairs or replacements of damaged segments are very rare in the case of SFRC segments. The production process also eliminates the need for accurate placement of the reinforcement.

A disadvantage of SFRC structures is the absence of structural design standards. European standards (Eurocodes - EC) still cover only the field of laboratory testing and production of fibres. There are only various guidelines and recommendations for structural design. This means that there is an absolute lack of uniformity in the design methods and required tests. A European standard for the design of SFRC structures is currently being prepared. The standard will be based on EC 2 for concrete structures; parts focused on SFRC will be amended.

\section{Tests ON SFRC SAMPLES}

Laboratory tests on SFRC are similar to plain concrete tests. In contrast to plain concrete, the tensile strength or the equivalent tensile strength after cracking of SFRC structures can be taken into consideration. The effect of added fibres on increasing of the cube compressive strength, the tensile splitting strength and the equivalent flexural strength is not identical. Due to the added steel fibres, the tensile strength usually increases more than the compressive strength. SFRC therefore cannot be classified simply according to cube compressive strength, as plain concrete is. This is because the high tensile strength would not be fully utilized in the design of structures. Therefore laboratory test of SFRC should take this factor into account.

Laboratory tests of SFRC samples were carried out at the Czech Technical University in Prague (CTU). The major objective of the realised tests was to verify the properties of various SFRC mixtures, the impact of various types of fibres, and the impact of various dosages of fibres. All specimens were cast in the plant of the Slovak company Doprastav, in Senec. In the first stage, the samples were produced with Dramix RC $80 / 60$ BN fibres, produced by the Belgian company Bekaert, and with Czech fibres TriTreg. The fibre dosage was $70 \mathrm{~kg}$ for $1 \mathrm{~m}^{3}$ of concrete. A total of 30 cubes were produced with a side length of $150 \mathrm{~mm}$, and 30 beams with dimensions of $150 \times 150 \times 700 \mathrm{~mm}$. The samples were tested in three independent laboratories to increase the objectivity of the test results.

In the second stage, 12 beams and 12 cubes were produced with the same dimensions as in the first stage. The specimens were generated with Dramix $\mathrm{RC}-80 / 60 \mathrm{BN}$ fibres with a fibre dosage of $50 \mathrm{~kg}$ for $1 \mathrm{~m}^{3}$ of concrete. The second stage of the tests served mainly to compare the impact of various fibre dosages.

The samples were used for four types of tests; all samples were tested after 28 days. Cube compressive strength and tensile splitting strength were tested on cubes according to CSN EN $12390-3$ and according to ČSN EN 12390 - 6 respectively. The beams were tested for flexural strength according to the German DVB - Merkblatt guideline (four-point bending tests) and for residual equivalent flexural strength on a beam with a notch in the middle (three-point bending test), according to ČSN EN14651.

The four-point bending tests were executed with controlled deflection. The curves of load dependence on deflection were evaluated by calculating the area under this curve. The results of a low beam deflection can be used for the serviceability limit state; results 


\begin{tabular}{cccccc}
\hline Dosage of fibres & $f_{c t, L}[\mathrm{MPa}]$ & $f_{R, 1}[\mathrm{MPa}]$ & $f_{R, 2}[\mathrm{MPa}]$ & $f_{R, 3}[\mathrm{MPa}]$ & $f_{R, 4}[\mathrm{MPa}]$ \\
\hline $50 \mathrm{~kg} / \mathrm{m}^{3}$ & 6.364 & 6.759 & 7.012 & 6.196 & 5.511 \\
\hline $70 \mathrm{~kg} / \mathrm{m}^{3}$ & 6.977 & 8.930 & 8.916 & 6.892 & 5.306 \\
\hline
\end{tabular}

TABLE 1. Comparison of residual flexural strength calculated according to ČSN EN 14651 (three-point bending test)

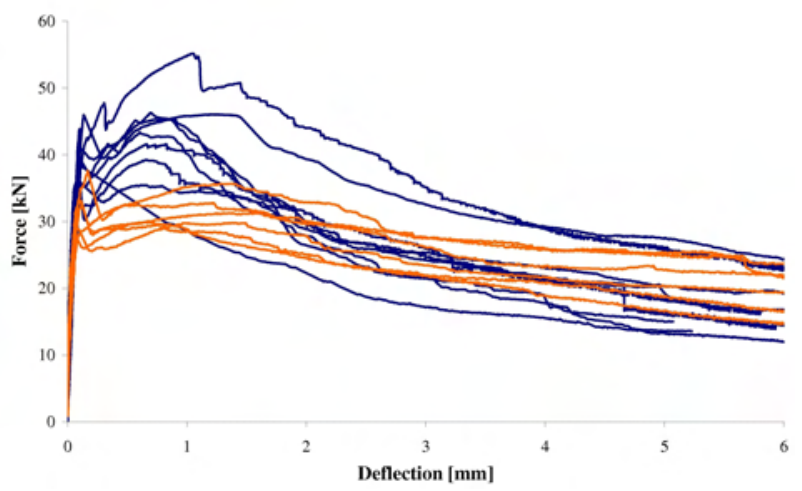

Figure 2. Comparison of four-point bending test results (blue: $70 \mathrm{~kg} / \mathrm{m}^{3}$ of Dramix fibres; orange: $50 \mathrm{~kg} / \mathrm{m}^{3}$ of Dramix fibres).

of a high beam deflection can be used for the ultimate limit state.

The three-point bending test can be used to evaluate the post-crack behaviour and to obtain the equivalent tensile strength at the determined crack opening [4]. The applied forces depending on crack mouth opening displacement (CMOD) were recorded during the test. The tensile strength of SFRC was calculated from the graph when the first crack appeared (LOP - limit of proportionality); and the post-crack residual flexural strength was calculated with the help of values given in the standard. Four residual strength values for SFRC were recorded $\left(f_{R, 1}, f_{R, 2}, f_{R, 3}\right.$ and $\left.f_{R, 4}\right)$ for four values of $\mathrm{CMOD}\left(\mathrm{CMOD}_{1}=0.5 \mathrm{~mm}, \mathrm{CMOD}_{2}=1.5 \mathrm{~mm}\right.$,

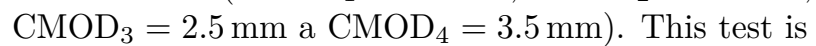
obligatory for manufacturers of fibres, because they have to state how many $\mathrm{kg}$ of fibres should be added to $1 \mathrm{~m}^{3}$ concrete to obtain residual strength of $1.0 \mathrm{MPa}$ at $\mathrm{CMOD}=3.5 \mathrm{~mm}$. This approach is not appropriate for the design of SFRC structures.

The results of the three-point bending tests that were carried out are presented in Tab. 1. They show an increase by about $25 \%$ in flexural strength between $50 \mathrm{~kg} / \mathrm{m}^{3}$ and $70 \mathrm{~kg} / \mathrm{m}^{3}$ dosages of fibres. The character of the resulting curves is presented in Fig. 2 Higher dosage of fibres leads to an increase in tensile residual strength after cracking up to deflection of about $3 \mathrm{~mm}$, and then the both curves are almost identical. The results show that tests with a lower dosage of fibres have a lower scatter of properties due to better workability of the mix with $50 \mathrm{~kg} / \mathrm{m}^{3}$ of fibres. However, samples with higher fibre dosages tend to have better final properties.

The performed tests could not provide an objective recommendation for the type of fibres for the produc-

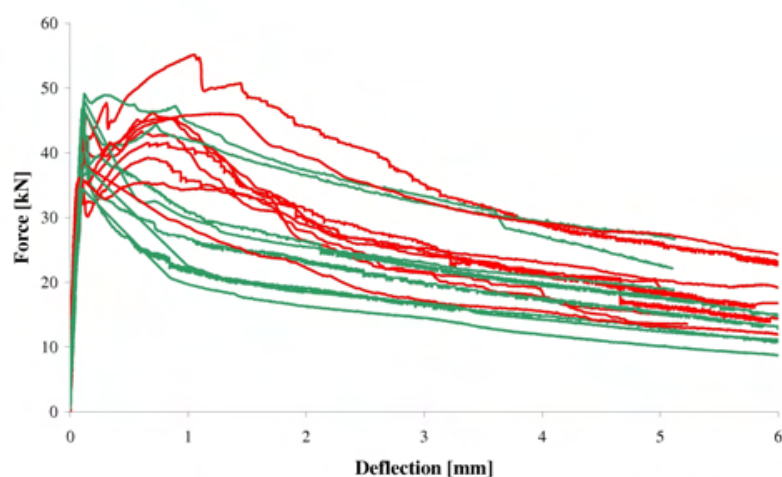

Figure 3. Comparison of four-point bending tests on beams with fibre dosage of $70 \mathrm{~kg} / \mathrm{m}^{3}$ (red: Dramix, green: TriTreg).

tion of SFRC segments. Further tests with various dosages of various fibres would be required to achieve higher confidence. SFRC beams with Dramix fibres generally had slightly better properties (Fig. 3). They had higher compressive strength and flexural strength. They also showed lower scatter due to better distribution of the fibres. SFRC beams with Dramix fibres also showed higher residual strength after cracking.

The results of the laboratory test showed that SFRC can be used for segments produced for the construction of Czech transport tunnels. The tests indicated that SFRC has properties that are important for segment design (especially compressive strength and flexural strength). In addition, the tests confirmed that a homogeneous SFRC mixture can be cast in the precast plant in Senec. Dramix fibres with a dosage of $50 \mathrm{~kg} / \mathrm{m}^{3}$ have been recommended for production and testing of SFRC segments.

\section{Numerical MODELling of SFRC BEAMS}

Many software products designed for numerical modelling of various civil structures are available on the market. It should be noted that a numerical model is only a specific approximation of the real behaviour of a structure. Modelling of SFRC structures should be performed in software that uses nonlinear fracture mechanics, because the postcracking behaviour is important for SFRC structures. The Czech software Atena was used for modelling the laboratory testing of SFRC beams. Back analysis was used for calibrating the SBeta material model. This problem cannot be solved using sophisticated methods (e.g. neural networks). The meaning of the individual parameters 


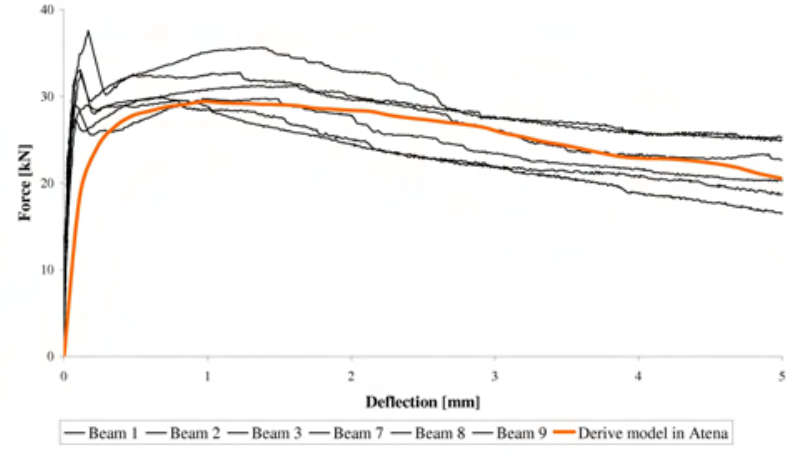

Figure 4. Comparison of testing and modelling (black: laboratory tests, orange: simulation, using Atena software).

\begin{tabular}{lc}
\hline Modulus of elasticity [GPa] & 40.66 \\
\hline Poisson's ratio [-] & 0.20 \\
\hline Tensile strength [MPa] & 4.20 \\
\hline Compessive strength [MPa] & -57.2 \\
\hline Specific fracture energy [N/m] & 7500 \\
\hline Critical compressive deformation $[\mathrm{m}]$ & -0.0005 \\
\hline
\end{tabular}

TABle 2. Parameters of the SBeta model derived by back analysis of the beams in Atena software

is known, and the parameters are almost independent. The parameters can be derived directly by gradually eliminating the differences between the test results and the modelling results.

The SBeta material model describes the behaviour of concrete in 2D models by fracture mechanics [6]. That it uses the crack-band concept with a nonlinear traction-separation law. The properties of concrete in tension are simulated by nonlinear mechanics in combination with the width of the cracked zone. The main parameters of the model are: tensile strength, fracture energy and the shape of the curve defined by the relationship between the stress and the crack opening. The parameters were derived by back analysis.

The four-point bending test of a beam without a notch was chosen for deriving the material parameters. This test simulates the behaviour of SFRC better than the test of the beam with a notch, which is better for calculating the fracture energy. The geometry, the support and the loading of the beam were the same as for the laboratory tests. The deflection at mid span and the value of the force were recorded in the simulation to compare the modelling results with the tests that were carried out. A comparison between the laboratory test and the simulation achieved by back analysis in Atena software is presented in a graph (Fig. 4). The curve derived by modelling does not match perfectly with the test results (the peaks are not included), but the prepared model can be used for a conservative prediction of the behaviour of the a)

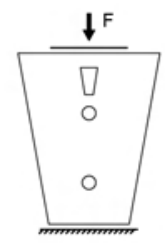

b)
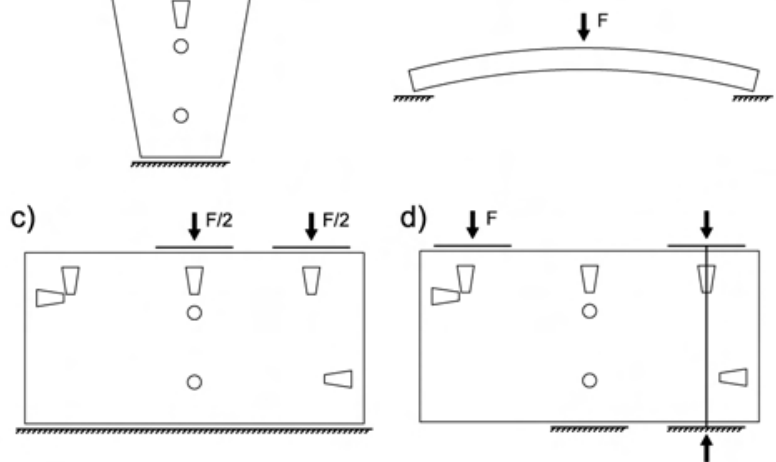

Figure 5. Tests performed on SFRC segments: (a) compressive strength of a key segment, (b) segment bending perpendicular to the segment plane, (c) compressive strength of the segment, (d) segment bending in the segment plane.

material.

The material parameters derived from back analysis of laboratory tests of SFRC beams (Tab. 2 served for a numerical simulation of the behaviour of an SFRC segment. Tests and mathematic simulations of entire SFRC segments should confirm the appropriateness of the derived SBeta parameters. Verification of the numerical model should be very useful for projects in future (as it will enable expensive laboratory tests on segments to be avoided).

\section{Tests on SFRC SEgments}

Tests on segments were executed at the Klokner Institute of CTU [3]. The segments were produced in Senec (Slovakia), where moulds for the construction of Prague metro line A extension are located. Two complete rings of SFRC segments were produced. The dosages of fibres were $40 \mathrm{~kg} / \mathrm{m}^{3}$ for one ring and $50 \mathrm{~kg} / \mathrm{m}^{3}$ for the second ring. Two major design cases were verified - long-term load of the installed lining (ground pressure and hydrostatic pressure) and the short-term load generated by shield rams pressure. Other temporary load cases can be adjusted in order not to increase the reinforcement.

The ultimate limit state is generally not crucial for the design of segments. The serviceability limit state plays a more important role, due to the importance of the watertightness of the tunnel lining. Impermeability of the segmental tunnel lining is generally guaranteed by waterproof concrete and gaskets between segments. The limiting factor for the design of the segmental tunnel lining is therefore a crack running through a segment allowing water leakage through the segment. SFRC is advantageous from this point of view, because macro-cracks appear later than in traditionally reinforced concrete. On the other hand reinforced concrete has significantly higher flexural 

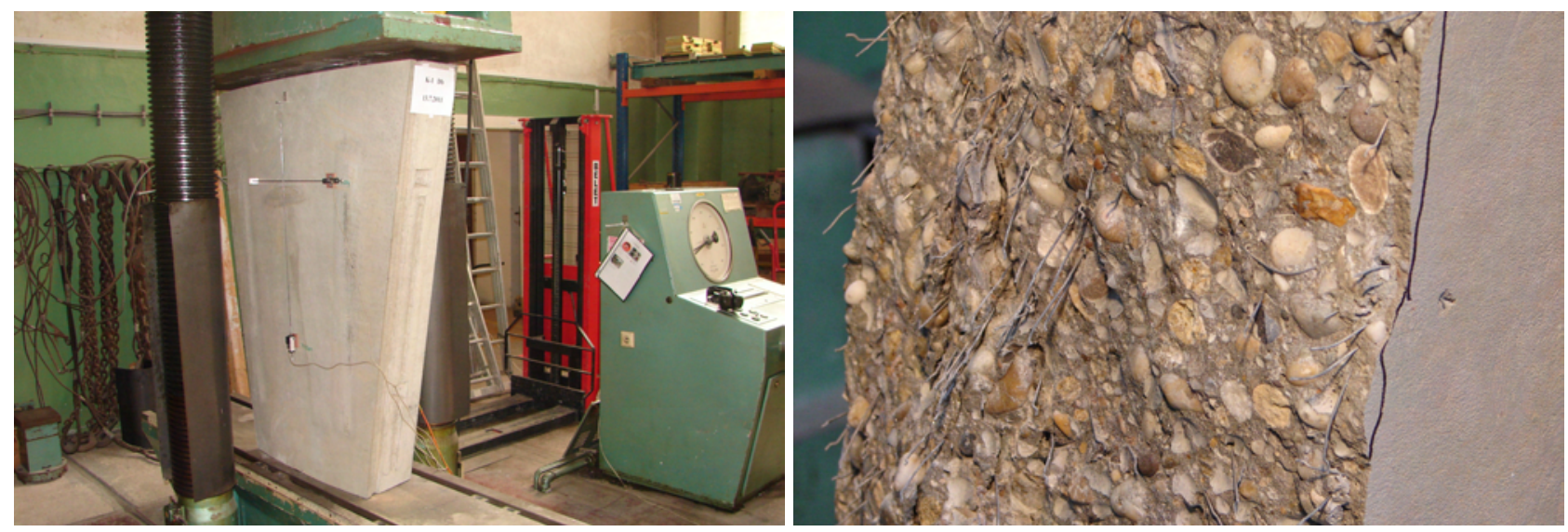

FigURE 6. Key segment compression (left: segment installed in the test machine; right: detail of the fractured surface).
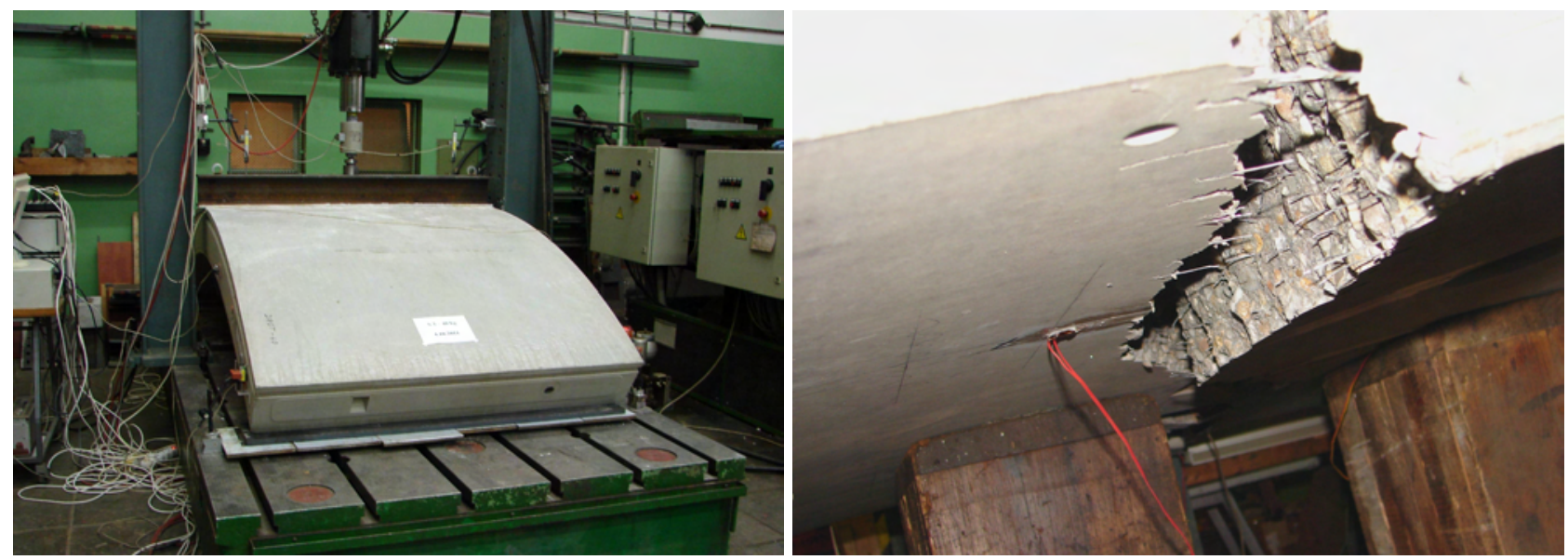

FiguRE 7. Segment bending (left: segment installed in the test machine; right: a detail of the fractured surface).

strength, but this is not important for the serviceability limit state.

SFRC segments were subjected to the following laboratory tests (Fig. 5).

\subsection{KEY SEGMENT COMPRESSION}

First, an SFRC key segment was tested in compression in the direction parallel to the longitudinal tunnel axis (Fig. 5a). The load simulated pressure generated by shield rams caused by penetrating the shield machine to the rock mass. The applied force was recorded during the test. Deformations were measured by potentiometric sensors and by resistance tensiometers glued to the surface of the segments. The laboratory test was conducted in a WPM $6000 \mathrm{kN}$ hydraulic machine (Fig. 6) with gradually increasing compressive force. The applied force was increased in steps of $300 \mathrm{kN}$, and the segment was unloaded to $90 \mathrm{kN}$ after each load step. The load was continuous from a value of $4800 \mathrm{kN}$.

The first crack appeared at an applied force of $4200 \mathrm{kN}$. The crack ran through the whole thickness of the segment. The maximum applied force was $6000 \mathrm{kN}$, when the available capacity of the testing machine was reached. The maximum load capacity of the key segment was not detected, so the segment had to be tested in the stronger Amsler $10000 \mathrm{kN}$ test machine. The key segment was tested by continuous loading until destruction, which occurred with a sudden break at a force of about $7250 \mathrm{kN}$.

A test of an RC key segment in compression was also executed. The dimensions of the segment were identical with the SFRC segment, and the setting of the test was also the same. The only difference was that the RC segment included a gasket (a sealing rubber) on its surface. The first crack occurred at a force of $3300 \mathrm{kN}$. The crack ran through the whole thickness of the segment. The maximum applied force was about $5870 \mathrm{kN}$. At this force, separation of a large part of cover at the inner surface of key stone occurred.

\subsection{Segment Bending}

Segments were also tested under a load perpendicular to the longitudinal tunnel axis (Fig. 5p). The test simulated segment bending caused by ground pressure. The segment was laid in convex position, and the lower edges were supported by sliding mats, allowing horizontal movement and preventing vertical movement. The segment was loaded with a uniform load along the whole length of the crown (Fig. 7). 

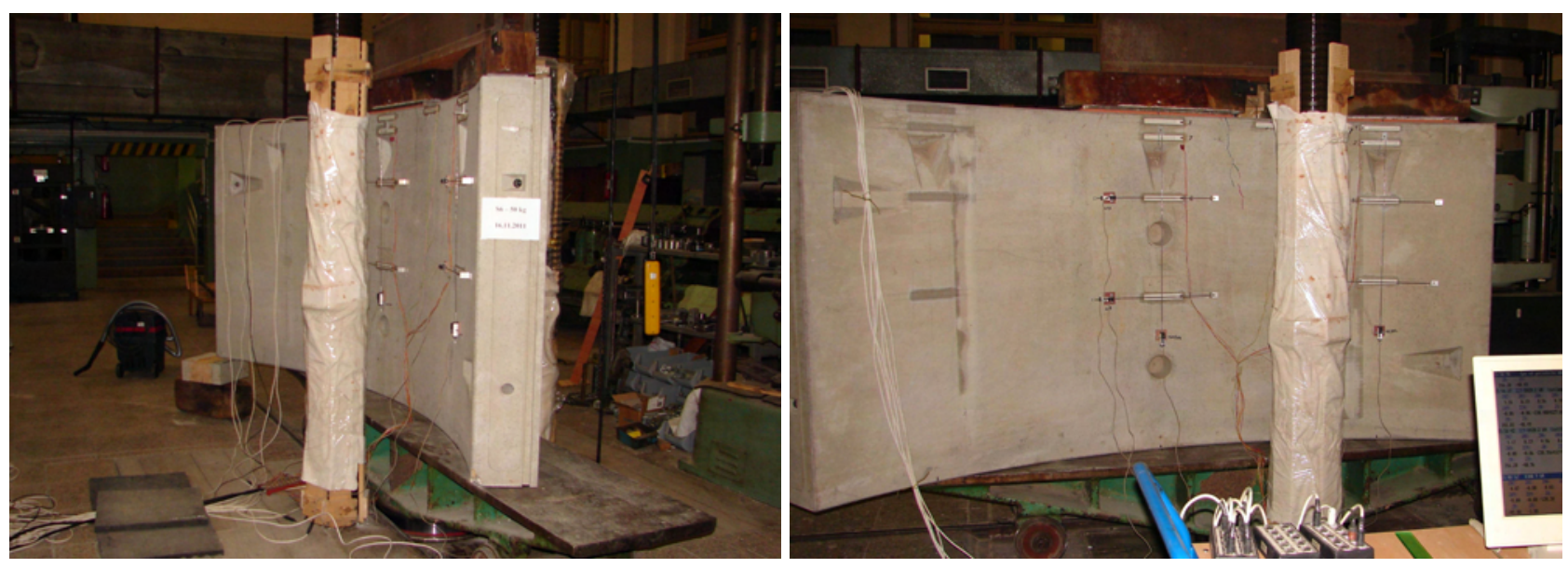

FIGURE 8. Compression of a uniformly supported segment.
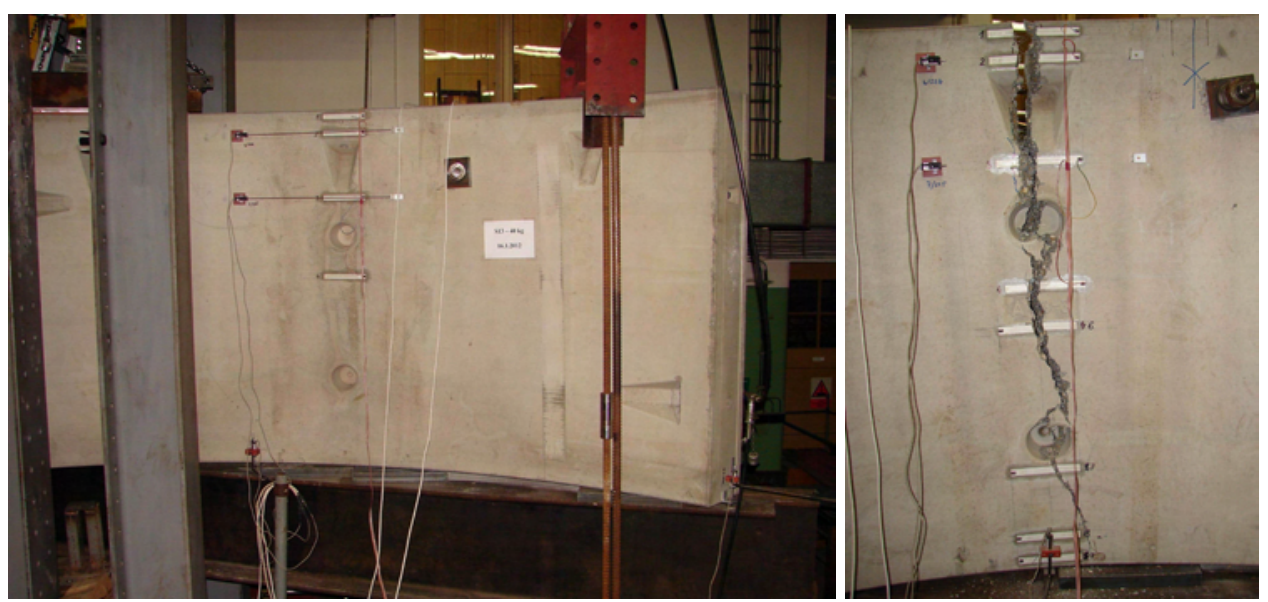

FiguRE 9. Compression of a non-uniformly supported segment (left: segment installed in the test machine; right: detail of the fractured segment).

The test was controlled by increasing the deflection to obtain the whole stress-strain diagram, including the decreasing section. The test was finished once the segment disintegrated under its self-weight.

The first cracks emerged on the bottom surface of the segment in a relatively wide zone under the applied load. Cracks gradually spread in this zone, then one dominant crack appeared, and then the failure of the segment occurred. The load capacity was relatively low, and the segment failed at a maximum load between $100 \mathrm{kN}$ and $150 \mathrm{kN}$. A total of four SFRC segments were tested using this type of test.

\subsection{COMPRESSION OF A UNIFORMLY SUPPORTED SEGMENT}

This test simulated a uniform load of the shield rams. Segments were loaded by a force parallel to the longitudinal tunnel axis. The segment was loaded in two points in the centre plane (Fig. 5 ). The applied force was increased in steps of $1200 \mathrm{kN}$; the segment was unloaded to $400 \mathrm{kN}$ after each step.

Two SFRC segments were subjected to this test. The first crack appeared in both cases under a force of $3600 \mathrm{kN}$. Subsequently cracks developed between two applied forces, mainly on the external surface of the segment. A crack running through the whole thickness of the segment appeared under loads of $6000 \mathrm{kN}$ and $6600 \mathrm{kN}$. The maximum force that was reached was $9000 \mathrm{kN}$ and $9300 \mathrm{kN}$. Both segments failed by splitting in the area between the applied forces.

\subsection{Compression of A NON-UNifORMLY SUPPORTED SEGMENT}

This test was prepared to simulate segment bending in the segment plane (i.e. high cantilever bending). This kind of load occurs if the geometric assembly of the preceding ring is inaccurate, and the ring loaded by rams is not supported uniformly. The segments were supported by two supports (central and side support), support of the one side was omitted. The segment was loaded in the centre plane on the unsupported side. The tested segment was supported and loaded as a high cantilever (Fig. $5 \mathrm{~d}$ ).

The segment was loaded by increasing the force without unloading, with force increments of $100 \mathrm{kN}$, up to failure of the segment. Four SFRC segments were tested using this test; the test was also performed 


\begin{tabular}{|c|c|c|c|c|c|}
\hline Segment & $\begin{array}{c}\text { Dosage } \\
\text { of fibers } \\
{\left[\mathrm{kg} / \mathrm{m}^{3}\right]}\end{array}$ & $\begin{array}{c}\text { Increments } \\
\text { of applied force } \\
{[\mathrm{kN}]}\end{array}$ & $\begin{array}{c}\text { Unload } \\
\text { to the force } \\
{[\mathrm{kN}]}\end{array}$ & $\begin{array}{c}\text { Appearance crack } \\
\text { throught the segment } \\
\text { thickness } \\
{[\mathrm{kN}]}\end{array}$ & $\begin{array}{c}\text { Maximum } \\
\text { applied force } \\
{[\mathrm{kN}]}\end{array}$ \\
\hline \multicolumn{6}{|c|}{ Loading by bending perpendicular to the segment plane (Fig. $5 \mathrm{~b}$ ) } \\
\hline $\mathrm{S} 1$ & 40 & continually & not unloaded & - & 115 \\
\hline $\mathrm{S} 2$ & 50 & continually & not unloaded & - & 106 \\
\hline S3 & 40 & continually & not unloaded & - & 124 \\
\hline $\mathrm{S} 4$ & 50 & continually & not unloaded & - & 154 \\
\hline \multicolumn{6}{|c|}{ Loading unaxial compression of segment (Fig. 5a, 5c) } \\
\hline $\mathrm{K}$ & 50 & 300 & 90 & 4200 & 7247 \\
\hline $\mathrm{S} 1-\mathrm{L}$ & 40 & 600 & 200 & 6000 & 6600 \\
\hline $\mathrm{S} 2-\mathrm{L}$ & 50 & 600 & 200 & 4800 & 7500 \\
\hline $\mathrm{S} 3-\mathrm{L}$ & 40 & 600 & 200 & 6000 & 6600 \\
\hline $\mathrm{S} 3-\mathrm{P}$ & 40 & 600 & 200 & 6000 & 7480 \\
\hline $\mathrm{S} 4-\mathrm{L}$ & 50 & 600 & 200 & 5400 & 8300 \\
\hline $\mathrm{S} 4-\mathrm{P}$ & 50 & 600 & 200 & 6000 & 7900 \\
\hline $\mathrm{S} 5$ & 40 & 1200 & 400 & 6000 & 9000 \\
\hline $\mathrm{S} 6$ & 50 & 1200 & 400 & 6000 & 9300 \\
\hline \multicolumn{6}{|c|}{ Loading by bending in the segment plane (Fig. $5 \mathrm{~d})$} \\
\hline $\mathrm{S} 11$ & 50 & 100 & not unloaded & 200 & 500 \\
\hline $\mathrm{S} 12$ & 50 & 100 & not unloaded & 300 & 753 \\
\hline $\mathrm{S} 13$ & 40 & 100 & not unloaded & 300 & 629 \\
\hline S14 & 40 & 100 & not unloaded & 300 & 610 \\
\hline
\end{tabular}

TABLE 3. Results of laboratory tests on SFRC segments.

with traditionally reinforced segments.

The first cracks appeared under a load of about $300 \mathrm{kN}$. The segment began to break almost in the middle, where the segments are weakened by a niche for the connecting bolt. Many tiny cracks parallel to the axis of the tunnel also appeared. Subsequently, the segment cracked in the middle. The maximum force that was attained was of about $600 \mathrm{kN}$. A similar maximum force of about $600 \mathrm{kN}$ was achieved for the RC segments. A crack through the whole thickness of the segment formed in the SFRC segment later than in the RC segment. The corresponding force was $500 \mathrm{kN}$ for the SFRC segment, and $400 \mathrm{kN}$ for the RC segment.

\subsection{Evaluation of the tests on SFRC SEGMENTS}

The test results gave a realistic idea about the behaviour of the SFRC segments, and also about their bending capacity and serviceability. The biggest advantage of SFRC segments is the larger number of small cracks in initial stages of loading. This is beneficial from the serviceability limit state point of view.
A crack through the whole thickness of the segment appears later in SFRC segments than in RC segments. The risk of water leakage is therefore lower for SFRC segments. The tests showed that SFRC segments can replace widely-used RC segments.

The results of our laboratory tests of SFRC segments are summarized in Tab. 3 .

\section{A SECTION OF SFRC SEGMENTAL LINING INSTALLED IN THE PRAGUE METRO}

The successful laboratory tests on SFRC segments led to the decision to install SFRC segmental lining in the Prague metro. SFRC segments were installed in the construction of the line A extension. RC segments were normally used on the running tunnels of this project excavated by two EPB shields. The RC segments were produced at the precast plant in Senec, Slovakia. The SFRC segments were produced in the same factory. Dramix fibres were used, with a fibre dosage of $40 \mathrm{~kg} / \mathrm{m}^{3}$. A total of ten SFRC rings were assembled (i.e. 15 meters of lining - see Fig. 10. The 
segments were placed in the right tunnel tube in June 2012 between metro stations Veleslavín and Červený Vrch. No major problems occurred during production and assembly of the SFRC segments.

\section{Conclusion}

SFRC is increasingly used as a structural material for precast segmental tunnel linings excavated by tunnelling machines. In some cases SFRC is supplemented by steel bar reinforcement, while in other cases SFRC is used without steel cages. SFRC segments can bring many benefits during tunnel construction and operation. The following advantages of SFRC segments can be mentioned:

- possible price reduction (less steel is used, and there is faster production);

- easier production (less manual work, no problems with the shape and the position of cages);

- simpler placing of tunnel equipment (no risk of drilling to steel bars);

- reduced risk of segment damage during transportation and installation (the edges are reinforced by fibres);

- longer durability (no problems with corrosion).

Successful laboratory test results have confirmed the possibility of using SFRC segments in Czech transport tunnels. This finding has been confirmed by their application in the Prague metro. Our study supports future applications of SFRC segments in the Czech Republic.

\section{ACKNOWLEDGEMENTS}

Financial support from the Czech Science Foundation (GAČR) grant No. P104/10/2023 is gratefully acknowledged.

\section{REFERENCES}

[1] Rivaz B.: Steel fibre reinforced concrete (SFRC): The use SFRC in precast segment for tunnel lining, WTC 2008, Agra, India, 2007-2017

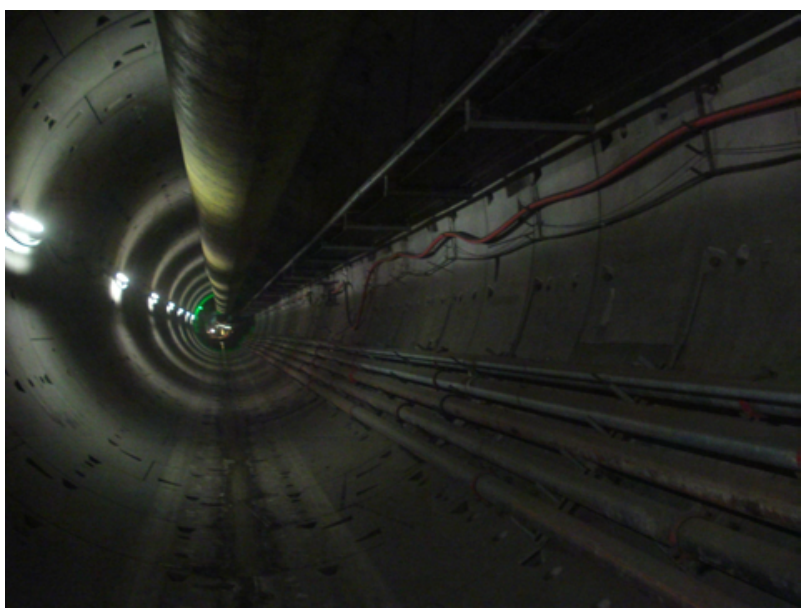

FIgURE 10. Section with SFRC segmental lining installed in Prague metro line A extension.

[2] Poh1 J., Tan K. H, Peterson G. L., Wen1 D.: Structural testing of steel fibre reinforced concrete (SFRC) tunnel lining segments in Singapore, WTC 2009, Budapest, Hungary

[3] Vokáč M., Bouška P.: Experimental testing of SFRC pre-cast metro segments, Klokner Institute, CTU in Prague, 2011-2012

[4] ČSN EN 14651: Zkušební metoda betonu s kovovými vlákny - Měření pevnosti v tahu za ohybu (mez úměrnosti, zbytková pevnost), 12/2008 (in Czech)

[5] Krátký J., Trtík K., Vodička J.: Drátkobetonové konstrukce - Směrnice pro navrhování, provádění, kontrolu výroby a zkoušení drátkobetonových konstrukcí, Česká společnost pro beton a zdivo, Česká komora autorizovaných inženýrů a techniků činných ve výstavbě, 1999 (in Czech)

[6] www . cervenka.cz/assets/files/atena-pdf/ATENA_ Theory.pdf

[7] Bendit de Rival, Dojčák J.: Normy a špecifikácie pre striekaný betón s rozptýlenou výstužou v tuneloch nového železničného spojenia Lyon - Turín, časopis Tunel, 19. ročník, č. $1 / 2010$, str. 38 - 43, Praha, 2010 